\title{
Capacity of graphene anode in ionic liquid electrolyte
}

\author{
Andrzej Lewandowski • Agnieszka Swiderska-Mocek • \\ Ewelina Rudnicka $\cdot$ Pawel Jakobczyk
}

Received: 3 April 2014 /Revised: 6 June 2014 / Accepted: 9 June 2014 / Published online: 19 June 2014

(C) The Author(s) 2014. This article is published with open access at Springerlink.com

\begin{abstract}
The graphene anode was investigated in an ionic liquid electrolyte $(0.7 \mathrm{M}$ lithium bis(trifluoromethanesulfonyl)imide $\left.\left(\operatorname{LiNTf}_{2}\right)\right)$ in room temperature ionic liquid $(N$-methyl- $N$ propylpyrrolidinium bis(trifluoromethanesulfonyl)imide $\left.\left(\mathrm{MPPyrNT}_{2}\right)\right)$. SEM and TEM images suggested that the electrochemical intercalation/deintercalation process in the ionic liquid electrolyte without vinylene carbonate (VC) leads to small changes on the surface of graphene particles. However, a similar process in the presence of $\mathrm{VC}$ results in the formation of a coating (SEI-solid electrolyte interface) on the graphene surface. During charging/discharging tests, the graphene electrode working together with the $0.7 \mathrm{M}$ LiNTf $_{2}$ in MPPyrNTf 2 electrolyte lost its capacity, during cycling and stabilizes at ca. $200 \mathrm{mAh} \mathrm{g}^{-1}$ after 20 cycles. The addition of $\mathrm{VC}$ to the electrolyte $(0.7 \mathrm{M}$ LiNTf $_{2}$ in MPPyrNTf +10 wt.\% VC) considerably increases the anode capacity. Electrodes were tested at different current regimes: ranging between 50 and $1,000 \mathrm{~mA} \mathrm{~g}^{-1}$. The capacity of the anode, working at a low current regime of $50 \mathrm{~mA} \mathrm{~g}^{-1}$, was ca. $1,250 \mathrm{mAh} \mathrm{g}^{-1}$, while the current of $500 \mathrm{~mA} \mathrm{~g}^{-1}$ resulted in capacity of $350 \mathrm{mAh} \mathrm{g}^{-1}$. Coulombic efficiency was stable and close to $95 \%$ during ca. 250 cycles. The exchange current density, obtained from impedance spectroscopy, was $1.3 \times 10^{-7} \mathrm{~A} \mathrm{~cm}^{-2}$ (at $298 \mathrm{~K}$ ). The effect of the anode capacity decrease with increasing current rate was interpreted as the result of kinetic limits of the electrode operation.
\end{abstract}

A. Lewandowski $(\bowtie) \cdot$ A. Swiderska-Mocek $\cdot$ E. Rudnicka $\cdot$ P. Jakobczyk Faculty of Chemical Technology, Poznań University of Technology, 60965 Poznań, Poland

e-mail: andrzej.lewandowski@put.poznan.pl

\section{Introduction}

Graphene, a two-dimensional sheet of $\mathrm{sp}^{2}$-bonded carbon atoms, is characterized by high electron conductivity and large specific surface area. It was demonstrated in 2008 that a pristine graphene anode may exhibit a high specific capacity (ca. $540 \mathrm{mAh} \mathrm{g}^{-1}$ ) [1]. During the last 5 years, a number of papers describing properties of graphene and graphenelike materials have been published. Different types of graphene, graphene-like or composite materials were tested: graphene $(\mathrm{G})$, graphene nano-sheets (GNS), graphene paper (GP), graphene foam (GF), reduced graphene oxide (RGO), microsphere multilayer graphene (MMS), graphene nanoflakes (GNFL), branched graphene nanosheets (BGNS), $\mathrm{G}+$ nanotubes $(\mathrm{G}+\mathrm{NT})$ and $\mathrm{GNS}+\mathrm{NT}$ [1-32]. In almost all cases, electrolyte is based on $1 \mathrm{M}$ $\mathrm{LiPF}_{6}$ solution in a mixture of carbonates. A solution of $\mathrm{LiClO}_{4}$ in a mixture of cyclic carbonates was also applied $[22,31]$. Usually, classical $\mathrm{Li}^{+}$solutions in volatile solvents, such as carbonates, have been applied. One paper reports the investigation of RGO/ionic liquid (IL) electrolyte system [15]. Comparison of literature data on graphene and graphene-like capacity is collected in Table 1 . Value of capacity $q$ (expressed in coulombs) was calculated as a product of current $I$ (galvanostatic charging-discharging), and time $t$ necessary to decrease the anode potential close to that characteristic of metallic lithium: $q=I t$. It is difficult to compare measured $q$ values, as they were determined in different current rates (expressed in $\mathrm{mAh} \mathrm{g}^{-1}$ or referred to the theoretical capacity of graphite: $372 \mathrm{mAh} \mathrm{g}^{-1}$ ). However, it was generally observed that the capacity, or rather $I t$ product, decreased with increasing current rate. In principle, this is equivalent to an assumption that the energy delivered by the power supplier is in $100 \%$ converted into the change of internal energy of the anode (its lithiation or delithiation). Possible energy 
Table 1 Literature data on graphene and graphene-like capacity towards lithium

\begin{tabular}{|c|c|c|c|c|}
\hline Graphene & Solvent & Salt & Capacity/mAh $\mathrm{g}^{-1}$ & Ref. \\
\hline GNS & $?$ & $?$ & $\begin{array}{l}540\left(50 \mathrm{~mA} \mathrm{~g}^{-1}\right) \text { after } 1 \text { cycle } \\
290\left(50 \mathrm{~mA} \mathrm{~g}^{-1}\right) \text { after } 20 \text { cycles }\end{array}$ & {$[1]$} \\
\hline GNS & $\mathrm{DMC}+\mathrm{DEC}+\mathrm{PC}(1: 1: 1)$ & $1 \mathrm{MLiPF}_{6}$ & $2,042-303\left(50 \mathrm{~mA} \mathrm{~g}^{-1}\right) 1$ st cycle & {$[2]$} \\
\hline GNS & $\mathrm{EC}+\mathrm{DMC}(1: 1)$ & $1 \mathrm{M} \mathrm{LiPF}_{6}$ & $554\left(1 \mathrm{~mA} \mathrm{~cm}{ }^{-2}\right)$ & [3] \\
\hline GNS & $\mathrm{EC}+\mathrm{PC}+\mathrm{DMC}(1: 1: 1)$ & $1 \mathrm{M} \mathrm{LiPF}_{6}$ & $350\left(40 \mathrm{~mA} \mathrm{~g}^{-1}\right)$ after 20 cycles & {$[4]$} \\
\hline GP & $?$ & $1 \mathrm{M} \mathrm{LiPF}_{6}$ & $100\left(50 \mathrm{~mA} \mathrm{~g}^{-1}\right)$ & {$[5]$} \\
\hline GNS & $\mathrm{EC}+\mathrm{DMC}(1: 1)$ & $1 \mathrm{MLiPF}_{6}$ & $\begin{array}{l}1,144\left(100 \mathrm{~mA} \mathrm{~g}^{-1}\right) ; \mid 936\left(300 \mathrm{~mA} \mathrm{~g}^{-1}\right) \\
718\left(500 \mathrm{~mA} \mathrm{~g}^{-1}\right) ; 445\left(1,000 \mathrm{~mA} \mathrm{~g}{ }^{-1}\right)\end{array}$ & [6] \\
\hline GF & $\mathrm{EC}+\mathrm{DMC}(1: 1)$ & $1 \mathrm{M} \mathrm{LiPF}_{6}$ & $\begin{array}{l}\text { ca. } 400\left(0.1 \mathrm{~A} \mathrm{~g}^{-1}\right) ; \text { ca. } 230\left(1 \mathrm{~A} \mathrm{~g}^{-1}\right) \\
\text { c. } 140\left(4 \mathrm{~A} \mathrm{~g}^{-1}\right)\end{array}$ & [7] \\
\hline RGO & $\mathrm{EC}+\mathrm{DMC}(1: 1)$ & $1 \mathrm{MLiPF}_{6}$ & $250\left(25 \mathrm{~mA} \mathrm{~g}^{-1}\right) ;$ after 40 cycles & {$[8]$} \\
\hline GP & $\mathrm{EC}+\mathrm{DMC}(1: 1)$ & $1 \mathrm{M} \mathrm{LiPF}_{6}$ & $\begin{array}{l}459-400\left(C / 7.4^{\mathrm{a}}\right) ; 230-193\left(1.3 \mathrm{C}^{\mathrm{a}}\right) ; \\
178-111\left(5.4 \mathrm{C}^{\mathrm{a}}\right)\end{array}$ & [9] \\
\hline GNS & $\mathrm{EC}+\mathrm{DMC}(1: 1)$ & $1 \mathrm{MLiPF}_{6}$ & $500\left(50 \mathrm{~mA} \mathrm{~g}^{-1}\right)$ after 30 cycles & {$[10]$} \\
\hline GNS & $\mathrm{EC}+\mathrm{DMC}+\mathrm{DEC}(1: 1: 1)$ & $1 \mathrm{M} \mathrm{LiPF}_{6}$ & $478\left(200 \mathrm{~mA} \mathrm{~g}^{-1}\right)$ after 100 cycles & {$[11]$} \\
\hline GNS & $\mathrm{EC}+\mathrm{DMC}(1: 1)$ & $1 \mathrm{M} \mathrm{LiPF}_{6}$ & $400\left(60 \mathrm{~mA} \mathrm{~g}^{-1}\right) ; 280\left(1,000 \mathrm{~mA} \mathrm{~g}^{-1}\right)$ & {$[12]$} \\
\hline MMG & $\mathrm{EC}+\mathrm{DMC}(1: 1)$ & $1 \mathrm{M} \mathrm{LiPF}_{6}$ & $200\left(25 \mathrm{~mA} \mathrm{~g}^{-1}\right) ; 60\left(120 \mathrm{~mA} \mathrm{~g}^{-1}\right)$ & {$[13]$} \\
\hline G & $\mathrm{EC}+\mathrm{DMC}+\mathrm{DEC}(1: 1: 1)$ & $1 \mathrm{M} \mathrm{LiPF}_{6}$ & $846-628\left(300 \mathrm{~mA} \mathrm{~g}^{-1}\right)$ & [14] \\
\hline RGO & MPPyrTFSI & LiTFSI & $550\left(50 \mathrm{~mA} \mathrm{~g}^{-1}\right)$ & {$[15]$} \\
\hline GNS & $\mathrm{EC}+\mathrm{DEC}(1: 1)$ & $1 \mathrm{MLiPF}_{6}$ & $835\left(50 \mathrm{~mA} \mathrm{~g}^{-1}\right)$ & [16] \\
\hline GP & $\mathrm{EC}+\mathrm{DEC}(1: 1)$ & $1 \mathrm{MLiPF}_{6}$ & $\begin{array}{l}545\left(372 \mathrm{~mA} \mathrm{~g}^{-1}\right) ; 370\left(1.86 \mathrm{~A} \mathrm{~g}^{-1}\right) \\
156\left(14.8 \mathrm{~A} \mathrm{~g}^{-1}\right)\end{array}$ & [17] \\
\hline GP & $\mathrm{EC}+\mathrm{DMC}+\mathrm{DEC}(1: 1: 1)$ & $1 \mathrm{M} \mathrm{LiPF}_{6}$ & $\begin{array}{l}557\left(200 \mathrm{~mA} \mathrm{~g}^{-1}\right) ; 268\left(500 \mathrm{~mA} \mathrm{~g}^{-1}\right) \\
169\left(1,000 \mathrm{~mA} \mathrm{~g}^{-1}\right) ; \\
141\left(1,500 \mathrm{~mA} \mathrm{~g}^{-1}\right)\end{array}$ & {$[18]$} \\
\hline RGO & $\mathrm{EC}+\mathrm{DEC}(1: 1)$ & $1 \mathrm{M} \mathrm{LiPF}_{6}$ & $89\left(50 \mathrm{~mA} \mathrm{~g}^{-1}\right)$ after 50 cycles & [19] \\
\hline GNS-NT & $\mathrm{EC}+\mathrm{DEC}(1: 1)$ & $1 \mathrm{MLiPF}_{6}$ & $485\left(74.4 \mathrm{~mA} \mathrm{~g}^{-1}\right)$ after 100 cycles & {$[20]$} \\
\hline GNS & $?$ & $?$ & $410\left(1 \mathrm{~A} \mathrm{~g}^{-1}\right) ; 235\left(5 \mathrm{~A} \mathrm{~g}^{-1}\right)$ & {$[21]$} \\
\hline GNFL & $\mathrm{EC}+\mathrm{DEC}(1: 1)$ & $1 \mathrm{M} \mathrm{LiClO}_{4}$ & $455\left(37 \mathrm{~mA} \mathrm{~g}^{-1}\right)$ after 10 cycles & {$[22]$} \\
\hline BGNS & $\mathrm{EC}+\mathrm{EMC}(4: 6)$ & $1 \mathrm{MLiPF}_{6}$ & $434\left(1 C^{a}\right)$ & {$[23]$} \\
\hline $\mathrm{G}+\mathrm{NT}$ & $\mathrm{EC}+\mathrm{DMC}(1: 1)$ & $1 \mathrm{M} \mathrm{LiPF}_{6}$ & $768\left(90 \mathrm{~mA} \mathrm{~g}^{-1}\right)$ after 100 cycles & {$[24]$} \\
\hline GNS & $\mathrm{EC}+\mathrm{DMC}(1: 1)$ & $1 \mathrm{M} \mathrm{LiPF}_{6}$ & $310\left(\mathrm{C} / 5^{\mathrm{a}}\right)$ after 30 cycles & {$[25]$} \\
\hline GNS & $\mathrm{EC}+\mathrm{DMC}(1: 1)$ & $1 \mathrm{M} \mathrm{LiPF}_{6}$ & $768\left(100 \mathrm{~mA} \mathrm{~g}^{-1}\right)$ after 10 cycles & {$[26]$} \\
\hline G & $\mathrm{EC}+\mathrm{DMC}(1: 1)$ & $1 \mathrm{M} \mathrm{LiPF}_{6}$ & $600\left(149 \mathrm{~mA} \mathrm{~g}^{-1}\right)$ after 100 cycles & {$[27]$} \\
\hline $\mathrm{G}$ & $\mathrm{EC}+\mathrm{DEC}(1: 1)$ & $1 \mathrm{M} \mathrm{LiPF}_{6}$ & $600\left(1 \mathrm{~A} \mathrm{~g}^{-1}\right)$ & {$[28]$} \\
\hline G-NT & $\mathrm{EC}+\mathrm{DMC}+\mathrm{EMC}(1: 1: 1)$ & $1 \mathrm{M} \mathrm{LiPF}_{6}$ & $298\left(50 \mathrm{~mA} \mathrm{~g}^{-1}\right)$ after 50 cycles & [29] \\
\hline G & - & - & $1,723\left(\mathrm{C} / 10^{\mathrm{a}}\right) ; 203\left(20 \mathrm{C}^{\mathrm{a}}\right)$ & {$[30]$} \\
\hline GNS & $\mathrm{EC}+\mathrm{DEC}(1: 1)$ & $1 \mathrm{M} \mathrm{LiClO}_{4}$ & $1,250\left(100 \mathrm{~mA} \mathrm{~g}^{-1}\right)$ & {$[31]$} \\
\hline GNS & $\mathrm{EC}+\mathrm{DMC}(1: 1)$ & $1 \mathrm{MLiPF}_{6}$ & $636\left(1 \mathrm{~mA} \mathrm{~cm}^{-2}\right)$ & {$[32]$} \\
\hline G & MPPyrTFSI & LiTFSI & $650\left(200 \mathrm{~mA} \mathrm{~g}{ }^{-1}\right) ; 350\left(500 \mathrm{~mA} \mathrm{~g}{ }^{-1}\right)$ & This work \\
\hline
\end{tabular}

$G$ graphene, GNS graphene nano-sheets, GP grapheme paper, $G F$ graphene foam, $R G O$ reduced graphene oxide, $M M S$ microspheres multilayer graphene, GNFL graphene nano-flakes, $B G N S$ branched graphene nano-sheets

${ }^{a}$ Referred to the theoretical capacity of graphite (372 $\mathrm{mAh} \mathrm{g}^{-1}$ )

exchange in the form of heat or kinetic limits of the process have been neglected in the capacity calculations. The general aim of this work was to examine the problem of graphene capacity using an ionic liquid electrolyte. Such a kind of a solvent-free electrolyte is characterized by practically negligible vapour pressure. Consequently, Li-ion cells consisting of only non-volatile components show suppressed flammability. The non-volatile ionic liquid electrolyte was obtained by dissolution of solid lithium bis(trifluoromethanesulfonyl)imide $\left(\operatorname{LiNTf}_{2}\right)$ salt in a salt liquid at room temperature ( $N$-methyl- $N$-propylpyrrolidinium bis(trifluoromethanesulfonyl)imide (MPPyrNTf ${ }_{2}$ )). 


\section{Experimental}

\section{Materials}

Lithium foil (0.75-mm thick, Aldrich), vinylene carbonate (VC, Aldrich), lithium bis(trifluoromethanesulfonyl)imide (LiNTf ${ }_{2}$, Fluka), single-layer graphene (G, obtained by reducing graphene oxide prepared by Hummer's method, specific surface $570 \mathrm{~m}^{2} \mathrm{~g}^{-1}$ (in micropores), average particle size $2.28 \mu \mathrm{m}$, ACS Material, USA), carbon black (CB, Alfa Aesar), poly(vinylidene fluoride) (PVdF, Fluka) and Nmethyl-2-pyrrolidinone (NMP, Fluka) were used as received from suppliers. $\mathrm{N}$-methyl- $\mathrm{N}$-propylpyrroldinium bromide (MPPyrBr) was obtained by reacting N-methylpyrrolidinium (Aldrich) with bromopropane (Aldrich) in acetone. Precipitated white MPPyrBr crystals were decanted, washed 5 times with n-hexane and dried under vacuum at $40{ }^{\circ} \mathrm{C} . N$-methyl- $N$ propylpyrrolidinium bis(trifluoromethanesulfonyl)imide $\left(\right.$ MPPyrNTf $_{2}$ ) was obtained from MPPyrBr and $\mathrm{LiNTf}_{2}$ solution in an aqueous medium. The ionic liquid phase was separated from the aqueous $\mathrm{LiBr}$ solution, washed 3 times with water and finally dried by evaporation in a vacuum at $50{ }^{\circ} \mathrm{C}$ for $10 \mathrm{~h}$. The solid LiNTf 2 salt was dissolved in the liquid salt MPPyrNTf $2\left(0.7 \mathrm{M}\right.$ solution of $\operatorname{LiNTf}_{2}$ in MPPyrNTf 2 ) to give the $\mathrm{Li}^{+}$-containing ionic liquid $\left[\mathrm{Li}^{+}\right]_{\mathrm{m}}[\mathrm{MPPyr}]_{\mathrm{n}}\left[\mathrm{NTf}_{2}\right]_{\mathrm{z}}$. The water content in the $\left[\mathrm{Li}^{+}\right]_{\mathrm{m}}[\mathrm{MPPyr}]_{\mathrm{n}}\left[\mathrm{NTf}_{2}\right]_{\mathrm{z}}$ electrolyte, analysed with a standard Karl-Fischer titrant (Aldrich), was below $0.4 \mathrm{mg} \mathrm{H}_{2} \mathrm{O} \mathrm{L}^{-1}$. Vinylene carbonate was stored at a max temperature of $8{ }^{\circ} \mathrm{C}$ to prevent its spontaneous polymerization. Electrolytes containing $\mathrm{VC}$ as a solid electrolyte interface (SEI)-forming additive (10 wt.\%) were prepared in a dry argon atmosphere in a glove box. Tested carbon electrodes were prepared on a copper foil (Hohsen, Japan) by the casting technique, from a slurry of graphene $(\mathrm{G})$, carbon black (CB) and PVdF in NMP. The ratio of components was $\mathrm{G} / \mathrm{CB} / \mathrm{PVdF}=70: 10: 20$ (by weight). After solvent (NMP) evaporation at $120^{\circ} \mathrm{C}$ in a vacuum, a layer of the carbon electrode was formed, containing the active material $(\mathrm{G})$, electronic conductor $(\mathrm{CB})$ and the binder (PVdF). The electrode contained typically $0.4-0.8 \mathrm{mg}$ of the graphene. A round-shaped metallic-lithium counterelectrode was cut off from the metallic-lithium foil (surface area of $1 \mathrm{~cm}^{2}$ ).

\section{Measurements}

Graphene|electrolyte|Li cells were assembled in a dry argon atmosphere in a glove box. The graphene $(\mathrm{G}+\mathrm{CB}+\mathrm{PVdF})$ and lithium electrodes were separated by a glass micro-fibre separator (GF/A, Whatman) soaked with the electrolyte. The graphene|electrolyte|lithium system was placed in an adapted $0.5^{\prime \prime}$ Swagelok ${ }^{\circledR}$ connecting tube. Electrochemical properties of cells were characterized using electrochemical impedance spectroscopy (EIS) and galvanostatic charge-discharge tests. The electrochemical graphene intercalation with lithium together with SEI formation was performed at different galvanostatic charging rates and times. Impedance spectra were obtained using a frequency response analyser at a frequency range of $100 \mathrm{kHz}-10 \mathrm{mHz}$, at the open circuit potential and amplitude of $10 \mathrm{mV}$ (G750 System Gamry, USA). Deconvolution of spectra was performed with the ZView software (Scribner Associates Inc., USA). The cycling tests on graphene|electrolyte|Li cells were performed between 0.001 and 3,000 V with the use of the ATLAS $0461 \mathrm{MBI}$ multichannel electrochemical system (Atlas-Sollich, Poland). The morphology of graphene electrodes (pristine and after electrochemical cycling) was analysed under electron microscopes (SEM, TESCAN Vega 5153, Czech Republic and TEM, JEOI JEM 1200 EXII, USA) and X-ray photoelectron spectroscopy (XPS) (Phoibos 150 NAP, SPECS GmbH, Germany).

\section{Results and discussion}

\section{SEI formation (SEM, TEM and XPS)}

Figure 1 shows SEM images of the pristine graphene and graphene after intercalation-deintercalation-intercalation process at two different magnifications. It can be seen that the electrochemical process in the ionic liquid without VC (Fig. 1c, d) leads to small changes on the surface of graphene particles. However, a similar process in the presence of $\mathrm{VC}$ results in the formation of a coating (SEI) on the surface (Fig. 1e, f). Corresponding TEM images (Fig. 2) also show differences in the surface between pristine graphene (Fig. 2a, b), after intercalation-deintercalation-intercalation

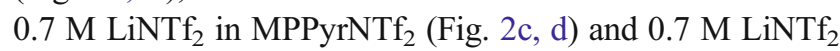
in MPPyrNTf $_{2}+10$ wt.\% VC (Fig. 2e, f). Again, galvanostatic charging/discharging of the graphene material in the electrolyte containing VC leads to the formation of a deposit on its surface (Fig. 2e, f). The XPS measurement (Fig. 3) reveals carbon (34.9\%), oxygen (28.9\%), fluorine (14.4\%), sulphur $(13.1 \%)$ nitrogen $(7.3 \%)$ and lithium $(1.2 \%)$ atoms at the graphene anode surface (covered with SEI layer, after 20 galvanostatic cycles). Such elements as N, O, S, F and Li indicate the presence of SEI coating and remains of the electrolyte on the graphene surface.

\section{Galvanostatic charging/discharging}

The graphene anode was tested in the ionic liquid electrolyte at different current densities. In all experiments, the mass of the counter-electrode (lithium, ca. $40 \mathrm{mg}$ ) was much higher in comparison to the mass of the graphene (ca. $0.4-0.8 \mathrm{mg}$ ). 
Fig. 1 SEM images of anode material: pristine graphene $(\mathbf{a}, \mathbf{b})$, after intercalation/deintercalation/ intercalation: in $0.7 \mathrm{M} \mathrm{LiNTf}_{2}$ in $\mathrm{MPPyrNTf}_{2}$ (c and d) and $0.7 \mathrm{M}$ LiNTf $_{2}$ in MPPyrNTf $_{2}+10$ wt. $\%$ $\operatorname{VC}(\mathbf{e}$ and $\mathbf{f})$
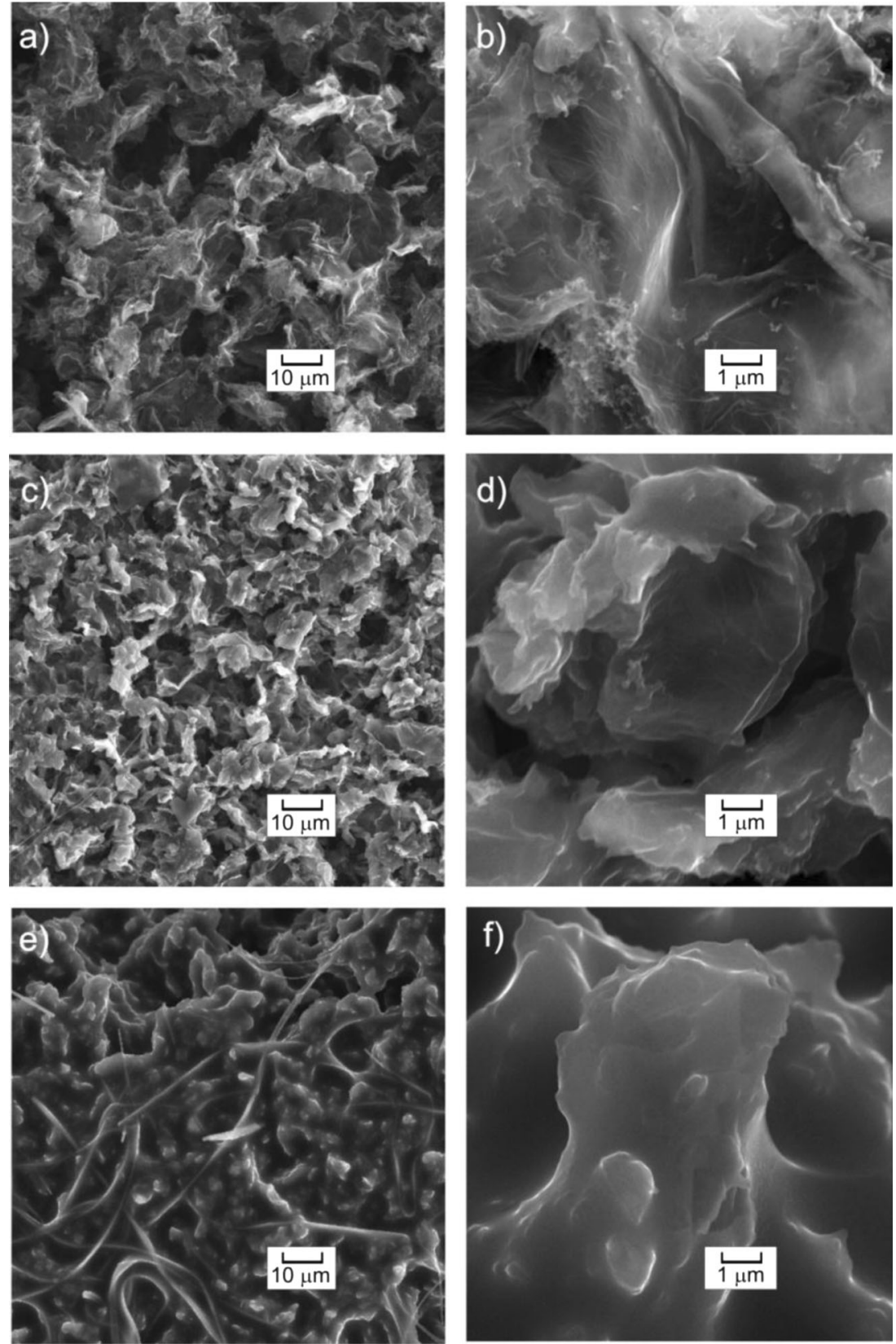

Figure 4 shows the charging/discharging curves for the graphene $\mathrm{Li}$ cell soaked with the electrolyte without VC. The product of time $t$ and current $I$, usually called the electrode capacity, changes during charging and discharging. It can be seen that the graphene electrode loses slowly its capacity during cycling and stabilizes at ca. $200 \mathrm{mAh} \mathrm{g}^{-1}$ after 20 cycles. In contrast to that, its coulombic efficiency is close to $100 \%$.

The addition of VC to the electrolyte (10 wt.\%) considerably increases the anode capacity. This phenomenon is due to the replacement of a resistive passivation layer (system without VC) by a SEI layer (prepared electrochemically from the electrolyte containing VC). Figure 5a presents the charging/ discharging profiles of the graphene $\mid$ Li cell soaked with the 0.7 $\mathrm{M} \mathrm{LiNTf}_{2}$ in MPPyrNTf $\mathrm{M}_{2}+10$ wt.\% VC electrolyte (current $50 \mathrm{~mA} \mathrm{~g}^{-1}$ ). It can be seen that the initial capacity of ca. $5,000 \mathrm{mAh} \mathrm{g}^{-1}$ (the first charging cycle) decreases to much lower values. The very high irreversible 'capacity' of the first cycle is probably due to the electrochemical SEI formation. Figure $5 \mathrm{~b}$ shows capacity of the graphene anode calculated for different current regimes: the first between 50 and $1,000 \mathrm{~mA} \mathrm{~g}^{-1}$. It may be seen that capacity decreases during initial cycles. For example, the $I t$ value decreased from the initial $1,300 \mathrm{mAh} \mathrm{g}^{-1}$ to ca. $1,200 \mathrm{mAh} \mathrm{g}^{-1}$ after the 10 th cycle $\left(I=50 \mathrm{~mA} \mathrm{~g}^{-1}\right)$. Increase of the current resulted in a reduction of the capacity, what is not unexpected. For 

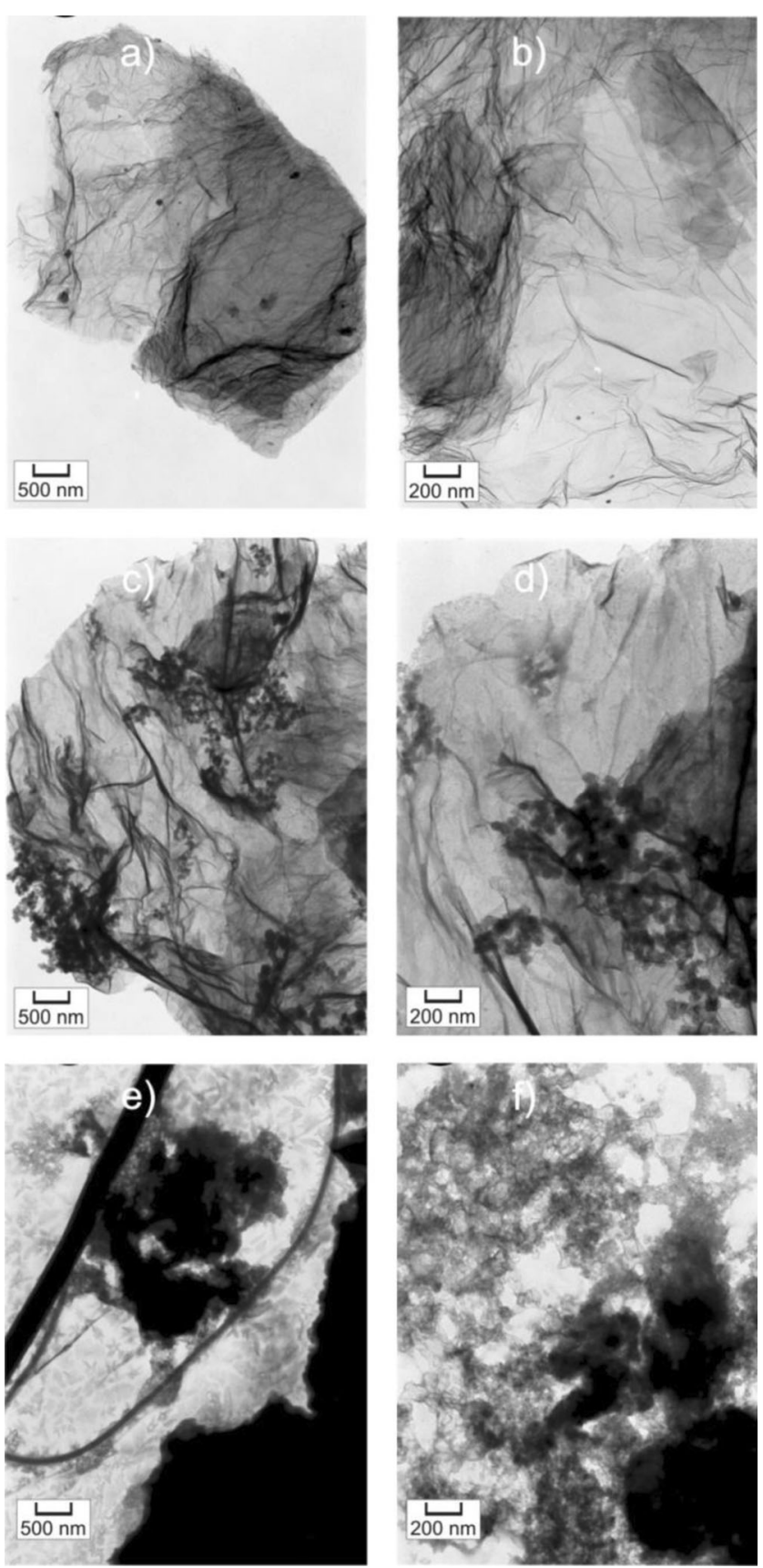

Fig. 2 TEM images of graphene anodes: pristine graphene (a and $\mathbf{b}$ ), after intercalation/deintercalation/intercalation: $0.7 \mathrm{M} \mathrm{LiNTf}_{2}$ in MPPyrNTf 2 (c and d) and $0.7 \mathrm{M} \mathrm{LiNTf}_{2}$ in $\mathrm{MPPyrNTf}_{2}+10$ wt.\% VC (e and $\mathbf{f}$ )

example, at the current of $500 \mathrm{~mA} \mathrm{~g}^{-1}$ (Fig. 5b), the $I t$ product is ca. $320-350 \mathrm{mAh} \mathrm{g}^{-1}$. When the current decreases, the capacity again increases, but to lower values. Coulombic efficiency is still stable and close to $95 \%$ after ca. 250 cycles (Fig. 6). Capacity values are much higher in comparison to those reported for the RGO electrode working with the same ionic liquid electrolyte. The graphene electrode shows the capacity of ca. $550 \mathrm{mAh} \mathrm{g}^{-1}$ at current densities of ca. $300 \mathrm{~mA} \mathrm{~g}^{-1}$, while the same value for the RGO anode was

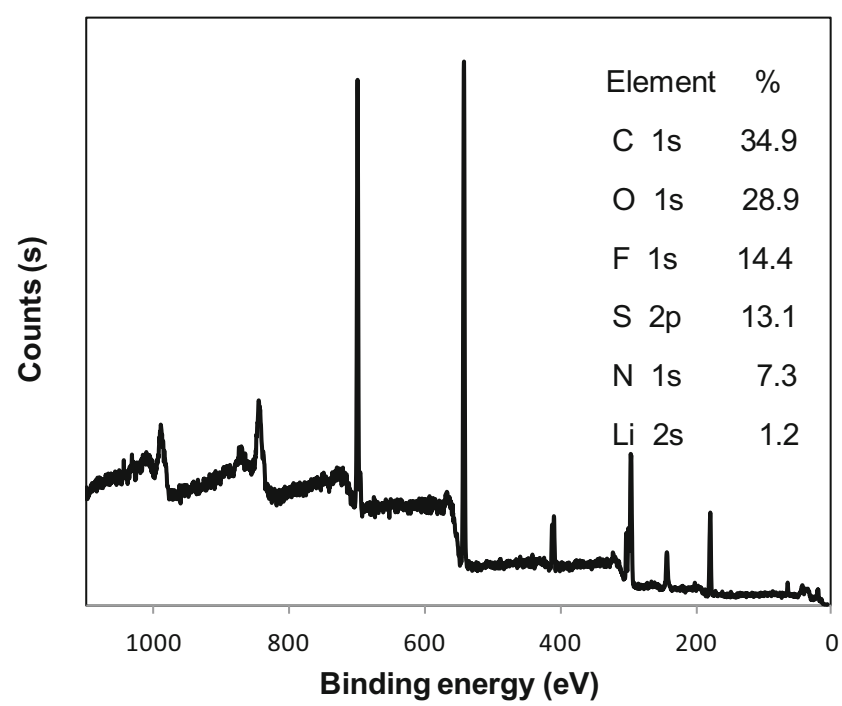

Figure 3 XPS spectrum of the graphene electrode after 20 charging/ discharging cycles (electrolyte, $0.7 \mathrm{M} \mathrm{LiNTf}_{2}$ in MPPyrNTf $2+10$ wt.\% $\mathrm{VC)}$

reported for a much lower current density of $50 \mathrm{~mA} \mathrm{~g}^{-1}$ [15]. In addition, the $I t$ product for the graphene is ca. $1,200 \mathrm{~mA} \mathrm{~g}^{-1}$ for $50 \mathrm{~mA} \mathrm{~g}^{-1}$ rate. In both cases, $\mathrm{VC}$ was used as a SEI-forming additive. Therefore, it may be concluded that graphene shows higher capacity in comparison to RGO, which probably still have some remaining oxygen groups.

\section{It product and 'electrode capacity'}

The dependence of the $I \times t$ product is usually interpreted as the capacity $q$ (charge expressed in $\mathrm{mAh} \mathrm{g}^{-1}$ ). It can be seen (Fig. $5 \mathrm{~b}$ ) that the $I \times t$ value decreases with increasing current. The $q=\mathrm{f}(I)$ curve may be fitted by a polynomial: $q=a+b I+c I^{2}$, with $a=1,410 \mathrm{mAh} \mathrm{g}^{-1} \cdot \mathrm{Li}^{+}$ion reduction and transferring $\mathrm{Li}$ atoms into the $\mathrm{C}_{6} \mathrm{Li}$ form (lithiated graphite) is associated with the capacity of $370 \mathrm{mAh} \mathrm{g}^{-1}$. Therefore, the specific capacity of $1,410 \mathrm{mAh} \mathrm{g}^{-1}$ divided by the latter value leads to 1,410 / $370=3.81 \approx 4$, suggesting the $\mathrm{C}_{6} \mathrm{Li}_{4}$ composition of the graphene anode. However, this may be practically obtained

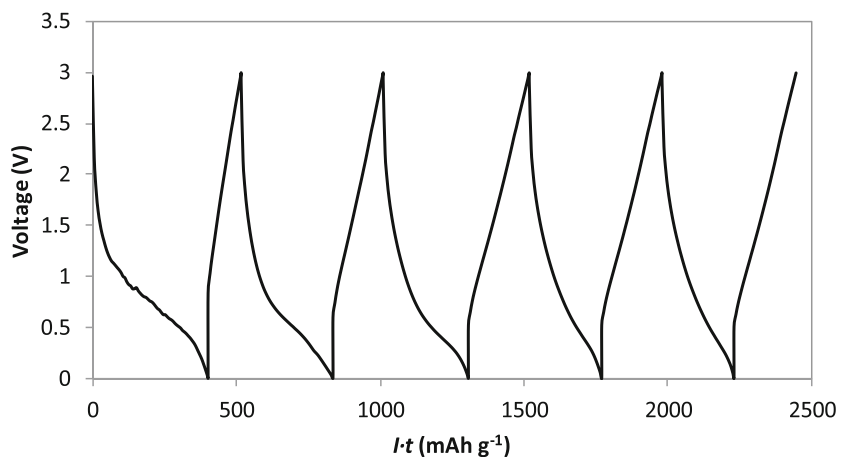

Fig. 4 Galvanostatic charging/discharging of the graphene|0.7 $\mathrm{M} \mathrm{LiNTf}_{2}$ in $\mathrm{MPPyrNTf}_{2} \mid \mathrm{Li}$ cell (without VC). $I=200 \mathrm{~mA} \mathrm{~g}^{-1}$ 

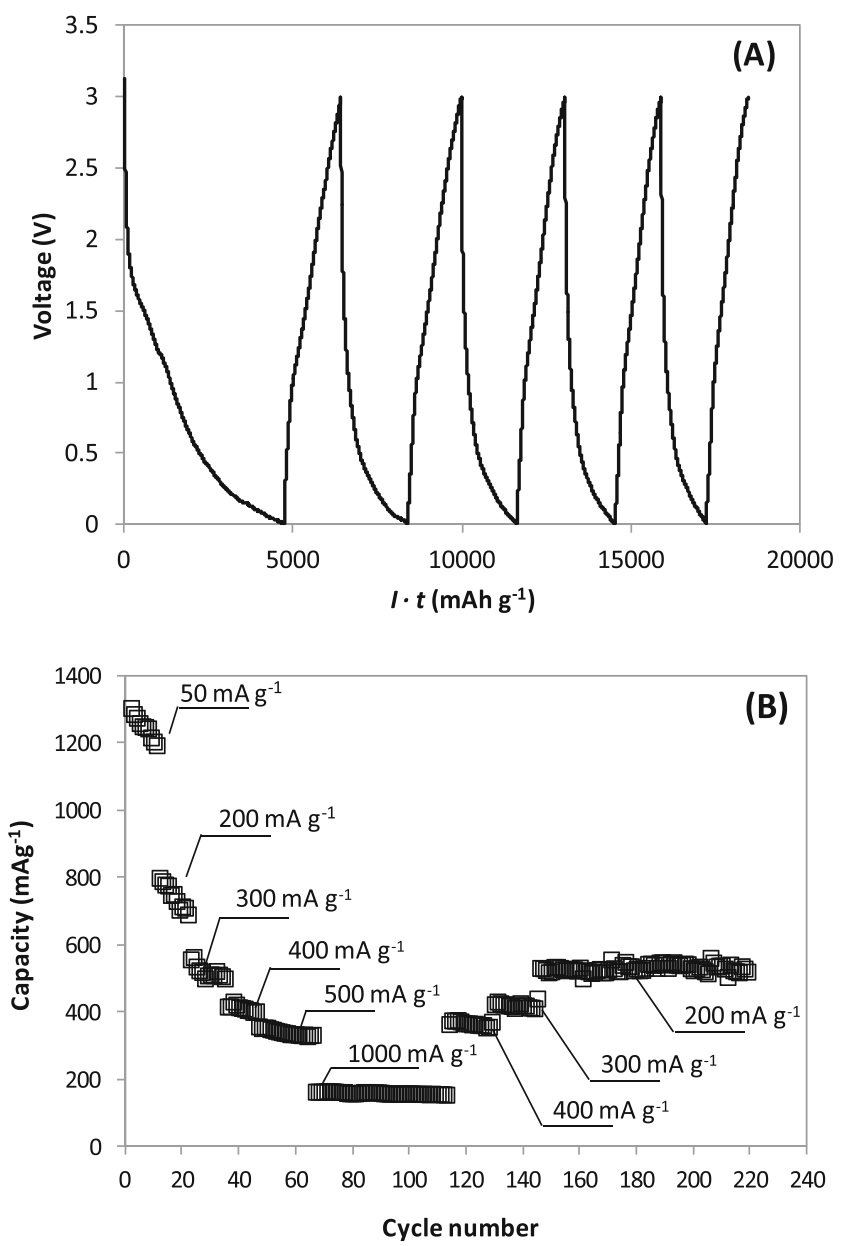

Fig. 5 a Galvanostatic charging/discharging of the graphene $\mid 0.7 \mathrm{M}$ $\mathrm{LiNTf}_{2}$ in MPPyrNTf ${ }_{2}+10 \mathrm{wt} . \% \mathrm{VC} \mid \mathrm{Li}$ cell. Graphene mass in the anode $0.48 \mathrm{mg}$, current $50 \mathrm{~mA} \mathrm{~g}^{-1}$. b 'Capacity' $\left(\mathrm{mAh} \mathrm{g}^{-1}\right.$ ) of the graphene anode (It product) for different currents $\left(\mathrm{mA} \mathrm{g}^{-1}\right)$. Graphene mass in the anode $0.76 \mathrm{mg}$

only at low current rates due to the kinetic control of the overall process.

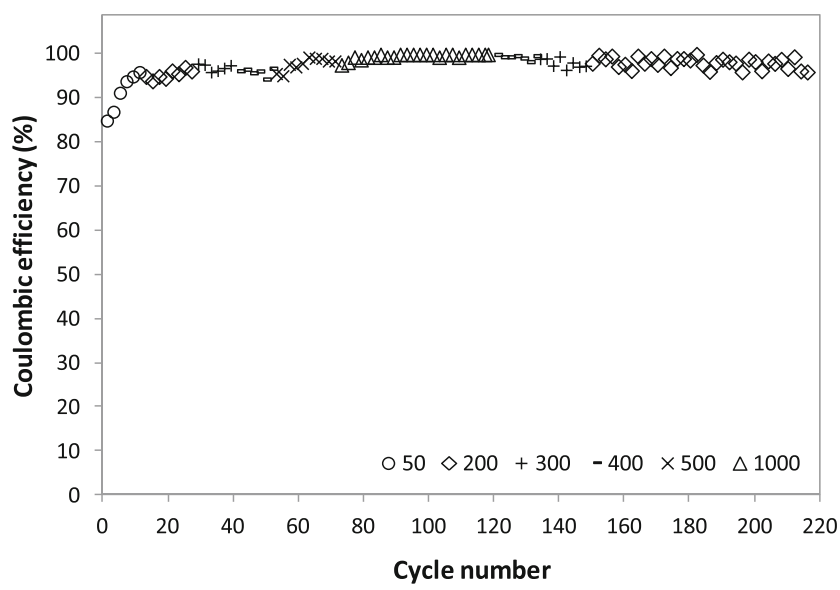

Fig. 6 Coulombic efficiency of the graphene $\mid 0.7 \mathrm{M} \mathrm{LiNTf}_{2}$ in MPPyrNTf ${ }_{2}+10$ wt.\% VC|Li cell for different currents $(200,300,400$, $\left.500,1,000 \mathrm{~mA} \mathrm{~g}^{-1}\right)$. Graphene mass in the anode $0.76 \mathrm{mg}$

\section{Kinetics}

The effect of the anode capacity decrease with increasing current rate is probably partially due to the kinetic limits of the electrode operation. Kinetic parameters of electrode processes were deduced from resistances obtained by deconvolution of EIS curves recorded at different temperatures, according to procedures and models available in the literature [33-35]. The intercalation mechanism of $\mathrm{Li}$ into graphite, distinguishing different relaxation steps (see Fig. 8 in ref. [33]) was adopted here for the graphene. The model assumes the following steps: $\mathrm{Li}^{+}$migration and diffusion in the electrolyte and SEI, charge transfer reaction and then $\mathrm{Li}$ diffusion in the solid electrode. EIS spectroscopy of the lithiated graphene recorded in an electrolyte without $\mathrm{VC}$ as SEI-forming additive (after 20 cycles, $I=150 \mathrm{~mA} \mathrm{~g}^{-1}$ ) showed very high impedances (up to $14 \mathrm{k} \Omega$ ) due to the passivation of the electrode surface. However, EIS curves recorded (at different temperatures) for the intercalated graphene covered with the SEI layer (due to the VC presence in the electrolyte) show much lower impedance (Fig. 7a). Curves consist of a 'flat semicircle' at higher frequency and a straight line at lower frequency. The shape of the 'flat semicircle' is a result of a combination of at least two time constants $R C$, due to the SEI layer $\left(R_{\mathrm{SEI}}, C_{\mathrm{SEI}}\right)$ and the charge transfer process which occurs at the double layer formed between SEI and the anode $\left(R_{\mathrm{ct}}\right.$, $\left.C_{\mathrm{dl}}\right)$. The strait line at the low-frequency section is due to the $\mathrm{Li}^{+}$and Li diffusion. Deconvolution of spectra was performed according to the equivalent circuit presented in Fig. 7b. The three resistances $\left(R_{\mathrm{el}}, R_{\mathrm{SEI}}, R_{\mathrm{ct}}\right)$ obtained from the fitting

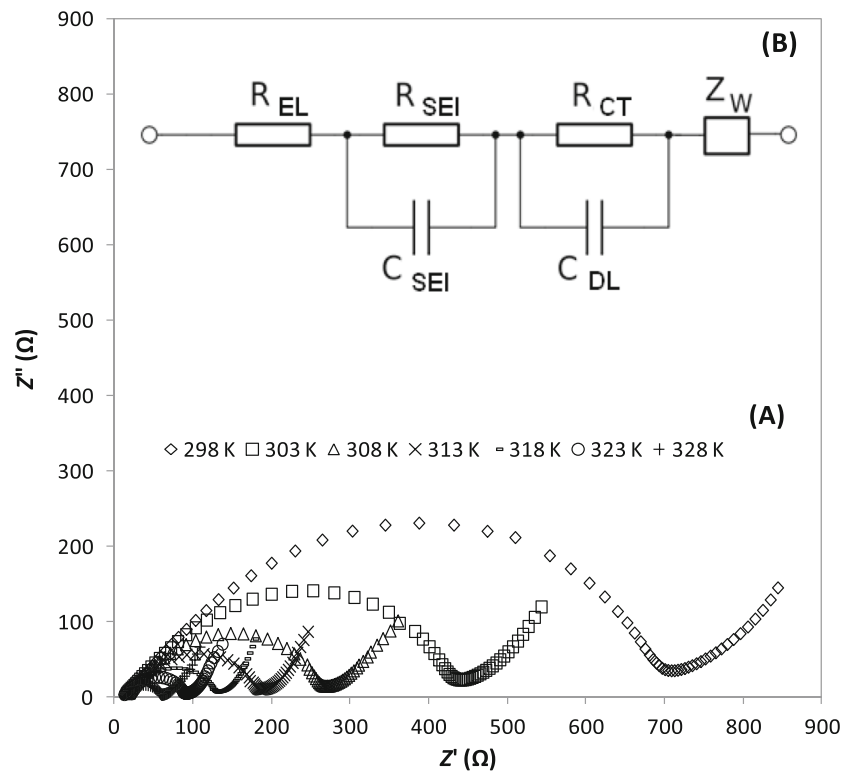

Fig. 7 a Impedance spectra of the lithiated graphene $/ \mathrm{SEI} / \mathrm{Li}^{+}$system recorded after 20 galvanostatic charging/discharging cycles at different temperatures. Electrolyte $0.7 \mathrm{M} \mathrm{LiNTf}_{2}$ in MPPyrNTf $\mathrm{M}_{2}+10 \mathrm{wt} . \% \mathrm{VC} . I=$ $150 \mathrm{~mA} \mathrm{~g}^{-1}$. b Equivalent circuit representing the graphene/SEI/electrolyte system 
procedure of EIS data taken at different temperatures, gave three $\ln R^{-1}=\mathrm{f}\left(T^{-1}\right)$ straight lines of different slopes, indicating activation energies $E^{\#}$. Resistance of the electrolyte layer in the separator (ca. 0.26-mm thick) and in electrode pores was ca. $8 \Omega$ at room temperature. Activation energy $E_{e l}^{\#}$ of the electrolyte conduction process, determined from the slope of the Arrhenius $\ln R_{\mathrm{el}}{ }^{-1}=\mathrm{f}\left(T^{-1}\right)$ plot, was $20.1 \mathrm{~kJ} \mathrm{~mol}^{-1}$. Resistance associated with the first time constant $\left(R_{\mathrm{SEI}}, C_{\mathrm{SEI}}\right)$ was as high as $540 \Omega$ at $298 \mathrm{~K}$, to decrease to $35 \Omega$ at $328 \mathrm{~K}$. Activation energy for the conduction process in the SEI layer was as high as $72.7 \mathrm{~kJ} \mathrm{~mol}^{-1}$ (solid phase).

The SEI layer influences the kinetics of the charge transfer process, which takes place at the graphene|SEI interphase. The value of the charge transfer resistance, $R_{\mathrm{ct}}$, for $\mathrm{Li}^{+}$reduction/ oxidation was $75.6 \Omega$ at $298 \mathrm{~K}$ (the surface area $A$ of $0.44 \mathrm{mg}$ of graphene was $A=5.7 \times 10^{6} \mathrm{~cm}^{2} \mathrm{~g}^{-1} 0.44 \times 10^{-3} \mathrm{~g}=2.5 \times$ $10^{3} \mathrm{~cm}^{2}$ ). The exchange current density $j_{\mathrm{o}}=1.3 \times 10^{-7} \mathrm{~A} \mathrm{~cm}^{-2}$ (at $298 \mathrm{~K}$ ) may be calculated from the $R_{\mathrm{ct}}$ value according to the following:

$j_{\mathrm{o}}=\frac{R T}{F A} \frac{1}{R_{c t}}$

where $F$ and $R$ are Faraday and gas constants, respectively.

Obtained current density is three orders of magnitude lower in comparison to the corresponding value characteristic of metallic lithium electrode $\left(1.24 \times 10^{-4} \mathrm{~A} \mathrm{~cm}^{-2}\right.$ [36]) due to very high specific surface area of the graphene. Activation energy $E_{c t}^{\#}$ for the charge transfer process, detected from the $\ln R_{\mathrm{ct}}^{-1}=\mathrm{f}\left(T^{-1}\right)$ plot was $48.5 \mathrm{~kJ} \mathrm{~mol}^{-1}$. However, the reaction rate is probably limited mainly by Li diffusion in the solid graphene anode, suggested by a high Warburg constant (ca. $41.5 \Omega \mathrm{s}^{-1 / 2}$ at $\left.298 \mathrm{~K}\right)$.

\section{Conclusions}

SEM and TEM images suggest that the electrochemical intercalation/deintercalation process in the ionic liquid electrolyte without VC leads to small changes on the surface of graphene particles. However, a similar process in the presence of $\mathrm{VC}$ results in the formation of a coating (SEI) on the graphene surface. The capacity of the graphene was expressed as the product of charging/discharging time $t$ and current $I$. During charging/discharging tests, the graphene electrode working together with the $0.7 \mathrm{M} \mathrm{LiNTf}_{2}$ in $\mathrm{MPPyrNTf}_{2}$ electrolyte lost its capacity during cycling and stabilized at ca. $200 \mathrm{mAh} \mathrm{g}^{-1}$ after 20 cycles.

The addition of $\mathrm{VC}$ to the electrolyte $\left(0.7 \mathrm{M} \mathrm{LiNTf}_{2}\right.$ in MPPyrNTf $_{2}+10 \mathrm{wt}$ \% $\%$ VC) considerably increased the anode capacity. Electrodes were tested at different current regimes ranging between 50 and $1,000 \mathrm{~mA} \mathrm{~g}^{-1}$. The capacity of the anode, working at a low current regime of $50 \mathrm{~mA} \mathrm{~g}^{-1}$, was ca. $1,250 \mathrm{mAh} \mathrm{g}^{-1}$, while the current of $500 \mathrm{~mA} \mathrm{~g}^{-1}$ resulted in a value of $350 \mathrm{mAh} \mathrm{g}^{-1}$. Coulombic efficiency was stable and close to $95 \%$ during ca. 250 cycles. The exchange current density was low $\left(1.3 \times 10^{-7} \mathrm{~A} \mathrm{~cm}^{-2}\right.$ at $\left.298 \mathrm{~K}\right)$ with relatively low corresponding resistance $\left(R_{\mathrm{ct}} \approx 75.6 \Omega\right)$, due to the high surface area of the graphene anode material $(5.7 \times$ $\left.10^{6} \mathrm{~cm}^{2} \mathrm{~g}^{-1}\right)$. The effect of the anode 'capacity' decrease with increasing current rate was interpreted as the result of kinetic limits of the electrode operation.

Acknowledgments Support of grants 31-254/13-DS.PB and NCN $\mathrm{UMO} / 2013 / 09 / \mathrm{B} / \mathrm{ST} / 00107$ are gratefully acknowledged.

Open Access This article is distributed under the terms of the Creative Commons Attribution License which permits any use, distribution, and reproduction in any medium, provided the original author(s) and the source are credited.

\section{References}

1. Yoo E, Kim J, Hosono E, Zhou HS, Kudo T, Honma I (2008) Nano Lett 8:2277-2282

2. Pan D, Wang S, Zhao B, Wu M, Zhang H, Wang Y, Jiao Z (2009) Chem Mater 21:3136-3314

3. Guo P, Song H, Chen X (2009) Electrochem Commun 11:1320-1324

4. Ji F, Li YL, Feng JM, Su D, Wen YY, Feng Y, Hou F (2009) J Mater Chem 19:9063-9067

5. Wang C, Li D, Too CO, Wallace GG (2009) Chem Mater 21:26042606

6. Lian P, Zhu X, Liang S, Li Z, Yang W, Wang H (2010) Electrochim Acta 55:3909-3914

7. Zhou X, Liu Z (2011) Materials Sci Eng. doi:10.1088/1757-899X/ 18/6/062006

8. Kumar A, Reddy ALM, Mukherjee A, Dubey M, Zhan X, Singh N, Ci L, Billups WE, Nagurny J, Mital G, Ajayan PM (2011) ACS Nano 5:4345-4349

9. Zhao X, Hayner CM, Kung MC, Kung HH (2011) ACS Nano 5: 8739-8749

10. Guo P, Song H, Chena X, Ma L, Wang G, Wang F (2011) Anal Chim Acta 688:146-155

11. Wan L, Ren Z, Wang H, Wang G, Tong X, Gao S, Bai J (2011) Diamond \& Related Mater 20:756-761

12. Xiao X, Liu P, Wang JS, Verbrugge MW, Balogh MP (2011) Electrochem Commun 13:209-212

13. Wei T, Wang F, Yan J, Cheng J, Fan Z, Song H (2011) J Electroanal Chem 653:45-49

14. Tong X, Wang H, Wang G, Wan L, Ren Z, Bai J (2011) J Solid State Chem 184:982-989

15. Galinski M, Acznik I (2012) J Power Sources 216:5-10

16. Xiang HF, Li ZD, Xie K, Jiang JZ, Chen JJ, Lian PC, Wu JS, Yu Y, Wang HH (2012) RSC Adv 2:6792-6799

17. Mukherjee R, Thomas AV, Krishnamurthy A, Koratkar N (2012) ACS Nano 6:7867-7878

18. Liu F, Song S, Xue D, Zhang H (2012) Adv Mater 24:1089-1094

19. Liu S, Chen K, Fu Y, Yu S, Bao Z (2012) Appl Surface Sci 258: 5299-5303

20. Chen S, Yeoh W, Liu Q, Wang G (2012) Carbon 50:4557-4565 
21. Chen XC, Wei W, Lv W, Su FY, He YB, Li B, Kang F, Yang QH (2012) Chem Commun 48:5904-5906

22. Kokai F, Sorin R, Chigusa H, Hanai K, Koshio A, Ishihara M, Koga Y, Hasegawa M, Imanishi N, Takeda Y (2012) Diamond \& Related Mater 29:63-68

23. Kim H, Wen Z, Yu K, Mao O, Chen J (2012) J Mater Chem 22: $15514-15518$

24. Vinayan BP, Nagar R, Raman V, Rajalakshmi N, Dhathathreyan KS, Ramaprabhu S (2012) J Mater Chem 22:9949-9956

25. Lee SH, Seo SD, Park KS, Shim HW, Kim DW (2012) Mater Chem Phys 135:309-316

26. Liu H, Miao C, Tang Z, Zheng X, Qin X, Zhang X (2012) Mater Letters 83:62-64

27. Vargas COA, Caballero A, Morales J (2012) Nanoscale 4:2083-2092
28. Chen W, Zhu Z, Li S, Chen C, Yan L (2012) Nanoscale 4:2124-2129

29. Chen T, Pan L, Yu K, Sun Z (2012) Solid State Ionics 229:9-13

30. Fan Z, Yan J, Ning G, Wei T, Zhi L, Wei F (2013) Carbon 60:538561

31. Lee W, Suzuki S, Miyayama M (2013) Ceram Int 39:S753-S756

32. Bai LZ, Zhao DL, Zhang TM, Xie WG, Zhang JM, Shen ZM (2013) Electrochim Acta 107:555-561

33. Levi MD, Aurbach D (1997) J Phys Chem B 101:4630-4640

34. Lewandowski A, Biegun M, Galinski M (2012) Electrochim Acta 63: 204-208

35. Lewandowski A, Swiderska-Mocek A, Waliszewski L (2012) J Solid State Electrochem 16:3391-3397

36. Lewandowski A, Biegun M, Galinski M, Swiderska-Mocek A (2013) J Appl Electrochem 43:367-374 